\title{
PENGARUH FASILITAS DAN SARANA PENUNJANG TERHADAP EFEKTIVITAS KEGIATAN BONGKAR MUAT SERTA DAMPAKNYA TERHADAP PENINGKATAN KINERJA KAPAL DI PT. PELINDO II (PERSERO) CABANG SUNDA KELAPA
}

\author{
Ari Soeti Yani \\ Fakultas Ekonomi dan Bisnis Universitas 17 Agustus 1945 Jakarta \\ arisoetiyani@gmail.com \\ Apriady \\ Fakultas Ekonomi dan Bisnis Universitas 17 Agustus 1945 Jakarta \\ apriady_one@yahoo.com
}

\begin{abstract}
This study aims to, partially, examine the effect of main and supporting facilities on the effectiveness of loading and discharging activities and the increasing of ship performance, the effect of the effectiveness of loading and discharging activities on ship performance; and simultaneously, examine the effect of main and supporting facilities on the effectiveness of loading and discharging activities and ship performance at PT. Pelindo II (Persero) of Sunda Kelapa Branch. The increasing of throughput will give a positive impact to the loading and unloading activities and the ship performance in the harbor. This study used secondary data sourced from company performance data in 2011-2015. Data were analyzed using linear regression. Results showed that, partially, main facilities had no significant effect on the effectiveness of loading and discharging activities and the ship performance; supporting facilities had a significant effect on the effectiveness of loading and discharging activities, but had no significant effect on ship performance; the effectiveness of loading and discharging activities had a significant effect on ship performance. Simultaneously, the main and supporting facilities have significant effects on the effectiveness of loading and discharging activities and the increasing of ship performance.
\end{abstract}

Keywords: Main Facilities, Supporting Facilities, Effectiveness of Unloading and Uploading Activity, Ship Performance.

\begin{abstract}
Abstrak: Penelitian ini bertujuan untuk, secara parsial, menguji pengaruh fasilitas dan sarana penunjang terhadap efektifitas kegiatan bongkar muat dan peningkatan kinerja kappa, dan pengaruh efektivitas kegiatan bongkar muat terhadap kinerja kapal, serta secara simultan menguji pengaruh fasilitas dan sarana penunjang terhadap efektivitas kegiatan bongkar muat dan kinerja kapal di PT. Pelindo II (Persero) Cabang Sunda Kelapa. Penambahan throughput akan berdampak positif pada kegiatan bongkar muat dan kinerja kapal di pelabuhan. Penelitian ini menggunakan data sekunder perusahaan yaitu data kinerja tahun 2011- 2015. Metode analisis data yang digunakan adalah analisis linear berganda. Hasil penelitian menunjukkan bahwa secara parsial, fasilitas tidak berpengaruh signifikan pada efektivitas kegiatan bongkar muat dan kinerja kapal; sarana penunjang berpengaruh signifikan pada efektivitas kegiatan bongkar muat namun tidak berpengaruh signifikan pada kinerja kapal; dan efektivitas kegiatan bongkar muat berpengaruh signifikan pada kinerja kapal. Secara simultan, fasilitas dan sarana penunjang berpengaruh signifikan pada efektivitas kegiatan bongkar muat dan kinerja kapal.
\end{abstract}

Kata Kunci: Fasilitas, Sarana Penunjang, Efektivitas Kegiatan Bongkar Muat, Kinerja Kapal 


\section{Pendahuluan}

Pelabuhan Sunda Kelapa merupakan salah satu cabang PT. Pelabuhan Indonesia II (Persero) yang saat ini sedang melakukan perbaikan kualitas kinerja kapal yang melakukan aktivitas bongkar muat. Hal ini dilakukan karena jumlah arus barang yang berada dilapangan dan gudang masih dianggap kurang maksimal. Hal ini dapat dilihat dari tabel persentasi dari Tahun 2011 - 2015.

Tabel 1. Laporan Kinerja Tahun 2011 - 2015

\begin{tabular}{cccccc}
\hline No & Tahun & $\begin{array}{c}\text { Storage } \\
\text { Occupacy Ratio } \\
\text { (\%) }\end{array}$ & $\begin{array}{c}\text { Yard Occupacy } \\
\text { Ratio (\%) }\end{array}$ & $\begin{array}{c}\text { Berth Occupacy } \\
\text { Ratio (\%) }\end{array}$ & $\begin{array}{c}\text { Turn Round } \\
\text { Time (\%) }\end{array}$ \\
\hline 1 & 2011 & 36.87 & 53.81 & 84.05 & 263.92 \\
2 & 2012 & 42.66 & 57.26 & 81.38 & 202.17 \\
3 & 2013 & 39.64 & 61.41 & 82.88 & 205.19 \\
4 & 2014 & 36.64 & 49.1 & 104.5 & 167 \\
5 & 2015 & 28.29 & 37.38 & 107.84 & 145 \\
\hline \multicolumn{5}{l}{ Sumber: Laporan Operasional PT. Pelindo II (Persero) Cabang Sunda Kelapa }
\end{tabular}

Pemakaian Berth Occupancy Ratio terus meningkat walaupun ditahun 2012 ada penurunan sebesar 2.67 persen. Hal ini menggambarkan tingkat kinerja dermaga cukup baik. Pada tahun 2012 sampai 2013 terjadi peningkatan Yard Occupancy Ratio, tetapi pada tahun 2014 dan 2015 mengalami penurunan yang cukup signifikan sebesar -12.31 dan -11.72 persen. Dari data tersebut pemakaian ruang lapangan mengalami penurunan dan untuk Storage Occupancy Ratio terus mengalami penurunan.Dari data yang didapat ruang penumpukan didalam gudang tidak dimanfaatkan secara maksimal sehingga selalu mengalami tingkat penurunan setiap tahunnya. Data Turn Round Time dapat dikatakan cukup baik bila diukur standar kepelabuhan Pelindo II Cabang Sunda Kelapa dengan hasil kinerja positif walau ada penurunan di tahun 2013. Dilihat dari manfaat fasilitas dan sarana penunjang yang ada, sangat jelas beberapa pendapat peneliti terdahulu bahwa pengembangan infrastruktur pelabuhan juga dapat mengembangkan pembangunan infrastruktur suatu wilayah Pelabuhan. Triatmodjo (2009) menyatakan kinerja pelabuhan dapat digunakan untuk mengetahui tingkat pelayanan pelabuhan kepada pengguna pelabuhan (kapal dan barang), yang tergantung pada waktu pelayanan kapal selama berada di pelabuhan. Kinerja pelabuhan yang tinggi menunjukkan bahwa pelabuhan tersebut dapat memberikan pelayanan yang baik. Kinerja suatu pelabuhan dapat di evaluasi dari sudut pandang efisiensi teknis, efisiensi biaya dan efektifitas. Efektifitas terkait dengan seberapa baik pelabuhan menyediakan pelayanan arus barang 
kepada pengguna perusahaan pelayaran atau pun ekspedisi. Beberapa penelitian yang menilai kualitas jasa pelabuhan menggunakan beberapa dimensi dan variabel yang beraneka ragam.

Posisi penelitian ini diantara penelitian-penelitian sebelumnya adalah bagaimana meningkatkan efektivitas bongkar muat dan kinerja kapal dalam pengaruh fasilitas serta sarana penunjang yang ada. Maka dari itu perlu dilakukan penelitian untuk meningkatkan pemanfaatan penggunaan fasilitas dan sarana penunjang dalam meningkatkan efektivitas kegiatan bongkar dan muat agar tercapai kinerja kapal yang baik di PT. Pelabuhan Indonesia II (Persero) Cabang Sunda Kelapa. Dengan adanya hasil perumusan masalah diatas, maka penelitian ini bertujuan untuk mengetahui pengaruh fasilitas dan sarana penunjang terhadap efektivitas kegiatan bongkar muat serta dampaknya terhadap peningkatan kinerja kapal Di PT. Pelindo II (Persero) Cabang Sunda Kelapa.

Beberapa teori yang digunakan dalam penelitian ini yaitu teori keagenan. Teori keagenan merupakan suatu hubungan kontraktual antara principals dan agents. Principals adalah yang memberikan tugas kepada pihak lain, yaitu agents yang akan melakukan semua kegiatan atas nama principals dalam kapasitasnya sebagai pengambil keputusan (Jensen dan Meckling, 1976). Principals (pemegang saham/pemilik/investor) menyediakan fasilitas dan dana untuk kebutuhan operasi perusahaan yang selanjutnya agent berkewajiban mengelola perusahaan dengan tujuan meningkatkan kemakmuran pemilik atau laba perusahaan.

Fasilitas dan efektivitas kegiatan bongkar muat Menurut Dundovic dan Hess (2005) yaitu kapasitas terminal sangat bergantung kepada kemampuan peralatan pelabuhan dalam melakukan bongkar muat. Menurut Salim (1993:104) Pelayanan barang pelabuhan adalah penyediaan jasa fasilitas gudang, lapangan penumpukan dan dermaga.Tingkat pelayanan pelabuhan dilihat dengan cara melihat kemampuan pelabuhan menangani jumlah barang yang masuk ke pelabuhan. Dari uraian diatas ditetapkan Hipotesis pertama yaitu. $\mathrm{H}_{1}$ :Fasilitas berpengaruh signifikan terhadap Efektivitas kegiatan Bongkar Muat dipelabuhan.

Terkait sarana penunjang dan efektivitas kegiatan bongkar dan muat. Menurut Solossa (2013) Berdasarkan hasil analisa menyimpulkan untuk mendapatkan perencanaan pengembangan dermaga pelabuhan dengan menitikberatkan pada panjang dermaga penumpang, panjang dermaga peti kemas, luas lapangan penumpukan peti kemas dan luas gudang. Tingkat risiko terjadinya lost time saat 
kegiatan Truck Losing Out dan Truck Losing In adalah sangat tinggi, sedangkan cetak job slip dan stack in adalah tinggi dan stack out adalah rendah.Dari uraian diatas ditetapkan Hipotesis kedua yaitu $\mathrm{H}_{2}$ : Sarana penunjang berpengaruh terhadap efektivitas kegiatan bongkar muat

Terkait fasilitas dan kinerja kapal, pengembangan model untuk mengetahui tingkat pengaruh penambahan faktor pelabuhan terhadap penambahan cargo through put, diketahui bahwa faktor yang berpengaruh positif adalah panjang dermaga, jumlah alat angkat, dan waktu operasional pelabuhan. Menurut Tongzon (2002) menggunakan beberapa variabel yang menentukan daya saing pelabuhan yaitu: efisiensi, frekuensi kunjungan kapal, kelengkapan infrastruktur, lokasi, biaya pelabuhan, respon yang cepat terhadap pengguna, serta reputasi terhadap kerusakan barang. Dari uraian diatas ditetapkan Hipotesis ketiga yaitu $\mathrm{H}_{3}$ : Fasilitas berpengaruh signifikan terhadap kinerja kapal di pelabuhan

Terkait sarana penunjang dan kinerja kapal, World bank (2004) menyatakan investasi infrastruktur berpengaruh secara signifikan kepada pembangunan, terutama pada tahap awal pembangunan suatu negara. Menurut Mujeri (2002) melihat besarnya dampak positif yang ditimbulkan dari pembangunan infrastruktur ini, Bank Dunia menyatakan bahwa investasi di bidang infrastruktur memiliki peranan yang jauh lebih besar daripada investasi dalam bentuk kapital lainnya.Sementara itu penelitian yang dilakukan Calderon dan Serven (2004) menunjukkan bahwa adanya dampak pengembangan infrastruktur pada pertumbuhan ekonomi dan distribusi pendapatan. Berdasarkan analisis kondisi eksisting dari Fasilitas dan peralatan menghasilkan cargo through put. Dengan penilaian kinerja operasional yang rata-rata adalah baik.Dari uraian diatas ditetapkan Hipotesis keempat yaitu $\mathrm{H}_{4}$ : Sarana penunjang berpengaruh signifikan terhadap Kinerja kapal.

Menurut Talley (2009) Kinerja suatu pelabuhan dapat di evaluasi dari sudut pandang efisiensi teknis, efisiensi biaya dan efektifitas menyatakan bahwa efektifitas terkait dengan seberapa baik pelabuhan menyediakan pelayanan arus barang kepada pengguna perusahaan pelayaran atau pun ekspedisi.Beberapa penelitian yang menilai kualitas jasa pelabuhan menggunakan beberapa dimensi dan variabel yang beraneka ragam. Menurut Kolanovic.et.al (2008) mendefiniskan variabel pelayanan pelabuhan berupa reliablitas dan kompetensi. Reliablitas terdiri dari 13 atribut yaitu penundaan dan keberangkatan kapal, waktu tunggu bongkar muat barang, rata-rata waktu kapal melakukan bongkar muat barang, waktu tunggu truk 
untuk melakukan bongkar muat barang di area terminal, waktu untuk melakukan transhipment, kesalahan dokumen, kelengkapan dokumen, kelengkapan informasi untuk kelengkapan dokumen, data statistik pelayanan, minimalisasi kegagalan dari pelayanan, monitoring kargo, kemampuan konsisten dalam melakukan pelayanan, dan jaminan ketepatan waktu operasional.Dari uraian diatas ditetapkan Hipotesis kelima yaitu $\mathrm{H}_{5}$ :Efektivitas kegiatan Bongkar Muat berpengaruh signifikan terhadap kinerja kapal dipelabuhan.

Hasil pengembangan model untuk mengetahui tingkat pengaruh penambahan faktor pelabuhan terhadap penambahan cargo through put, diketahui bahwa faktor yang berpengaruh positif adalah panjang dermaga, jumlah alat angkat, dan waktu operasional pelabuhan. Menurut Tongzon (2002) menggunakan beberapa variabel yang menentukan daya saing pelabuhan yaitu: efisiensi, frekuensi kunjungan kapal, kelengkapan infrastruktur, lokasi, biaya pelabuhan, respon yang cepat terhadap pengguna, serta reputasi terhadap kerusakan barang. Berdasarkan analisis kondisi eksisting dari fasilitas dan peralatan menghasilkan cargo through put dengan penilaian kinerja operasional yang rata-rata adalah baik.. Dari uraian diatas ditetapkan hipotesis keenam yaitu $\mathrm{H}_{6}$ : Fasilitas dan efektivitas kegiatan bongkar berpengaruh signifikan terhadap kinerja kapal dipelabuhan.

Menurut Solossa (2013) Berdasarkan hasil analisa menyimpulkan untuk mendapatkan perencanaan pengembangan dermaga pelabuhan dengan menitik beratkan pada panjang dermaga penumpang, panjang dermaga peti kemas, luas lapangan penumpukan peti kemas dan luas gudang. Menurut Tongzon (2002) menggunakan beberapa variabel yang menentukan daya saing pelabuhan yaitu: efisiensi, frekuensi kunjungan kapal, kelengkapan infrastruktur, lokasi, biaya pelabuhan, respon yang cepat terhadap pengguna, serta reputasi terhadap kerusakan barang. Berdasarkan analisis kondisi eksisting dari Fasilitas dan peralatan menghasilkan cargothroughputDengan penilaian kinerja operasional yang rata-rata adalah baik. Dari uraian diatas disimpulkan $\mathrm{H}_{7}$ : Sarana Penunjang dan Efektivitas kegiatan Bongkar Muat berpengaruh signifikan terhadap kinerja kapal dipelabuhan.

\section{Metodologi}

Jenis data penelitian yaitu data sekunder dan sumber data diperoleh dari, PT. Pelindo II (Persero) Cabang Sunda Kelapa, yaitu laporan kinerja operasional yang berisi tentang kinerja kapal, efisiensi kegiatan bongkar muat, fasilitas dan sarana penunjang selama 60 bulan. Metode analisis menggunakan regresi berganda, 
pengolahan data melalui SPSS. Adapun definisi dan pengukuran variabel penelitian sebagai berikut.

a. Variabel Dependen $(Y)$

1) Kinerja Kapal

Dalam penelitian ini yang dimaksud kinerja kapal adalah tingkat Turn Round Time yaitu merupakan tingkat waktu kapal ditambatan. Tingkat waktu kapal ditambatan diukur dari perbandingan antara TRT kapal dengan jumlah waktu di negara. Satuan pengukuran TRT adalah \%.

2) Efektivitas kegiatan bongkar muat (Z), yaitu tingkat Berth Occupancy Ratio yang merupakan tingkat efektif kegiatan bongkar muat di dermaga. BOR diukur dari perbandingan antara total waktu di dermaga terpakai dengan total waktu dermaga tersedia. Satuan pengukuran BOR adalah \%.

b. Variabel Independen

1) Fasilitas $\left(X_{1}\right)$ yaitu Yard Occupancy Ratio yang merupakan tingkat pemakaian kapasitas lapangan penumpukan, YOR diukur dari perbandingan antara total tonase barang dilapangan dengan holding capacity dilapangan satuan pengukuran YOR adalah \%.

2) Sarana Penunjang $\left(X_{2}\right)$ yaitu Storage Occupancy Ratio yang merupakan tingkat pemakaian kapasitas gudang. SOR diukur dari perbandingan antara total tenaga barang digudang dengan holding capacity dilapangan. Satuan pengukuran SOR adalah \%.

\section{Hasil dan Pembahasan}

\section{Hasil Penelitian}

Tabel 2. Hasil Pengolahan Data

\begin{tabular}{|c|c|c|c|c|c|c|c|c|}
\hline \multicolumn{9}{|c|}{ Coefficients $^{\mathrm{a}}$} \\
\hline & \multirow[b]{2}{*}{ Model } & $\begin{array}{l}\text { Unstar } \\
\text { Coef }\end{array}$ & $\begin{array}{l}\text { Irdized } \\
\text { ients }\end{array}$ & \multirow{2}{*}{$\begin{array}{c}\text { Standardize } \\
d \\
\text { Coefficients } \\
\text { Beta }\end{array}$} & \multirow[t]{2}{*}{$\mathbf{t}$} & \multirow[t]{2}{*}{ Sig. } & \multicolumn{2}{|c|}{ Collinearity Statistics } \\
\hline & & B & $\begin{array}{l}\text { Std. } \\
\text { Error }\end{array}$ & & & & Tolerance & VIF \\
\hline \multirow[t]{3}{*}{1} & (Constant) & 1.792 & .063 & & 28.253 & .000 & & \\
\hline & $X 1=$ GUDANG & -.088 & .046 & -.225 & -1.918 & .060 & .907 & 1.102 \\
\hline & $X 2=$ LAPANGAN & -.128 & .036 & -.421 & -3.586 & .001 & .907 & 1.102 \\
\hline
\end{tabular}

a. Dependent Variable: $Z=$ DERMAGA 
Coefficients $^{\mathrm{a}}$

\begin{tabular}{clccccccc}
\hline & & \multicolumn{3}{c}{$\begin{array}{c}\text { Unstandardized } \\
\text { Coefficients }\end{array}$} & \multicolumn{2}{c}{$\begin{array}{c}\text { Standardized } \\
\text { Coefficients }\end{array}$} & \multicolumn{3}{c}{ Collinearity Statistics } \\
& Model & B & Std. Error & Beta & t & Sig. Tolerance & VIF \\
\hline 1 & (Constant) & 3.150 & .342 & & 9.220 .000 & & \\
& X1= GUDANG & .052 & .066 & .084 & .785 & .436 & .852 & 1.173 \\
& X2 = LAPANGAN & -.011 & .055 & -.023 & -.203 .840 & .740 & 1.351 \\
& Z= DERMAGA & -1.023 & .184 & -.650 & - & 5.556 .000 & .714 & 1.401 \\
\hline
\end{tabular}

a. Dependent Variable: $Y=$ KINERJA KAPAL

Sumber: Data diolah

Tabel 3. Hasil Pengolahan Data

\begin{tabular}{|c|c|c|c|c|c|c|}
\hline \multicolumn{7}{|c|}{ ANOVA $^{b}$} \\
\hline \multicolumn{2}{|r|}{ Model } & Sum of Squares & Df & $\begin{array}{c}\text { Mean } \\
\text { Square }\end{array}$ & $\mathbf{F}$ & Sig. \\
\hline \multirow[t]{3}{*}{1} & Regression & .014 & 2 & .007 & 11.425 & $.000^{\mathrm{a}}$ \\
\hline & Residual & .035 & 57 & .001 & & \\
\hline & Total & .049 & 59 & & & \\
\hline
\end{tabular}

a. Predictors: (Constant), X2= LAPANGAN, X1= GUDANG

b. Dependent Variable: $Z=$ DERMAGA

\begin{tabular}{ccccccc}
\hline \multicolumn{7}{c}{ ANOVA $^{\mathrm{b}}$} \\
& Model & Sum of Squares & Df & Square & F & Sig. \\
\hline 1 & Regression & .054 & 3 & .018 & 15.443 & $.000^{\mathrm{a}}$ \\
& Residual & .066 & 56 & .001 & & \\
& Total & .120 & 59 & & & \\
\hline
\end{tabular}

a. Predictors: (Constant), Z= DERMAGA, X1= GUDANG, X2= LAPANGAN

b. Dependent Variable: $Y=$ KINERJA KAPAL

Sumber: Data diolah

Hipotesis pertama membuktikan secara parsial bahwa pengaruh Fasilitas/Gudang $\left(X_{1}\right)$ Terhadap Kegiatan Bongkar Muat/Dermaga (Z) adalah tidak signifikan, karena Sig 0,060>0,050, maka dapat disimpulkan bahwa variable Fasilitas/Gudang $\left(\mathrm{X}_{1}\right)$ tidak signifikan terhadap variable Kegiatan Bongkar Muat/Dermaga (Z).Berdasarkan pembuktian ini maka dapat disimpulkan Hipotesis Pertama $\left(\mathrm{H}_{1}\right)$ ditolak. Penyebab Fasilitas/Gudang tidak berpengaruh signifikan ialah karena pemanfaatan dan persiapan barang di dalam gudang yang masih belum maksimal untuk mempercepat kegiatan bongkar muat.

Hipotesis kedua membuktikan secara parsial bahwa pengaruh sarana penunjang/Lapangan $\left(\mathrm{X}_{2}\right)$ terhadap Kegiatan Bongkar Muat/Dermaga $(\mathrm{Z})$ adalah signifikan.Karena Sig 0.001<0.050, maka dapat disimpulkan Hipotesis kedua $\left(\mathrm{H}_{2}\right)$ 
diterima. Hipotesis Ketiga membuktikan secara parsial bahwa pengaruh Fasilitas/Gudang $\left(\mathrm{X}_{1}\right)$ terhadap Kinerja Kapal/TRT $(\mathrm{Y})$ adalah tidak signifikan, karena Sig 0,0436>0,050, maka dapat disimpulkan bahwa variable Fasilitas/Gudang ( $\left.X_{1}\right)$ tidak signifikan terhadap variable Kinerja Kapal/TRT (Y).Berdasarkan pembuktian ini maka dapat disimpulkan Hipotesis Ketiga $\left(\mathrm{H}_{3}\right)$ ditolak. Penyebab Fasilitas/Gudang tidak berpengaruh signifikan ialah karena pemanfaatan dan persiapan barang di dalam gudang yang masih belum maksimal untuk mempercepat tingkat waktu kapal saat berada ditambatan.

Hipotesis Keempat membuktikan secara parsial bahwa pengaruh Sarana Penunjang/Lapangan $\left(\mathrm{X}_{2}\right)$ terhadap Kinerja Kapal/TRT $(\mathrm{Y})$ adalah tidak signifikan, karena Sig 0,840>0,050, maka dapat disimpulkan bahwa variable Sarana Penunjang/Lapangan $\left(\mathrm{X}_{2}\right)$ tidak signifikan terhadap variable Kinerja Kapal/TRT (Y).Berdasarkan pembuktian ini maka dapat disimpulkan Hipotesis Keempat $\left(\mathrm{H}_{4}\right)$ ditolak. Penyebab Sarana Penunjang/Lapangantidak berpengaruh signifikan ialah karena pemanfaatan dan persiapan barang di lapangan penumpukan tidak dilakukan secara maksimal sehingga kapal terlalu lama menunggu barang ditambatan.

Hipotesis Kelima membuktikan secara parsial bahwa pengaruh Kegiatan Bongkar Muat/Dermaga (Z) Terhadap Kinerja Kapal/TRT (Y) adalah signifikan, karena Sig 0,000>0,050, maka dapat disimpulkan bahwa variable Kegiatan Bongkar Muat/Dermaga $\left(\mathrm{X}_{2}\right)$ signifikan terhadap variable Kinerja Kapal (Y).Berdasarkan pembuktian ini maka dapat disimpulkan Hipotesis Kelima $\left(\mathrm{H}_{5}\right)$ diterima

Hipotesis keenam pembuktian secara simultan dengan membandingkan antara $F$ hitung dengan $F$ table. Kolom $F$ hitung sebesar 15.443> $F_{\text {tabel2 }} .8$ (dilihat dari tabel distribusi F) yang berarti bahwa berpengaruh signifikan, maka dapat disimpulkan Hipotesis keenam $\left(\mathrm{H}_{6}\right)$ diterima. Hipotesis ketujuh pembuktian secarasimultan dapat dilihat pada tabel Anova pada kolom Sig. 0.000<0.005, yang berarti bahwa secara bersama sama berpengaruh signifikan, maka dapat disimpulkan Hipotesis ketujuh $\left(\mathrm{H}_{7}\right)$ diterima.

\section{Kesimpulan}

Tujuan dari penelitian ini adalah untuk membuktikan hipotesis yang telah diajukan diawal penelitian.Berikut adalah kesimpulan yang sekaligus merupakan jawaban dari permasalahan yang ada dalam penelitian ini. Sesuai dengan analisis data yang telah dilakukan, maka dapat ditarik kesimpulan sebagai berikut (a) Hasil pengujian hipotesis pertama ditemukan bukti empiris bahwa secara parsial, Yard 
Occupacy Ratio mempunyai pengaruh yang tidak signifikan terhadap Berth Occupacy Ratio. Arah pengaruh yang diberikan adalah pengaruh negatif, yang berarti pengaruhnya tidak searah. (b) Hasil pengujian hipotesis kedua ditemukan bukti empiris bahwa secara parsial,Shed Occupacy Ratiomempunyai pengaruh yang signifikan terhadap Berth Occupacy Ratio. Arah pengaruh yang diberikan adalah pengaruh positif, yang berarti pengaruhnyasearah. (c) Hasil pengujian hipotesis ketiga ditemukan bukti empiris bahwa secara parsial,Yard Occupacy Ratiomempunyai pengaruh yang tidak signifikan terhadapTurn Round Time.Arah pengaruh yang diberikan adalah pengaruh negatif, yang berarti pengaruhnya tidak searah. (d) Hasil pengujian hipotesis keempat ditemukan bukti empiris bahwa secara parsial, Shed Occupacy Ratiomempunyai pengaruh yang tidak signifikan terhadap Turn Round TimeArah pengaruh yang diberikan adalah pengaruh negatif, yang berarti pengaruhnya tidak searah. (e) Hasil pengujian hipotesis kelima ditemukan bukti empiris bahwa secara parsial, Berth Occupacy Ratio mempunyai pengaruh yang signifikan terhadap Turn Round Time di Pelabuhan sunda kelapa. Arah pengaruh yang diberikan adalah pengaruh positif, yang berarti pengaruhnya searah. (f) Hasil pengujian hipotesis keenamditemukan bukti empiris bahwa secara simultan Yard Occupacy Ratio dan Berth Occupacy Ratio berpengaruh signifikan terhadap Turn Round Time di Pelabuhan sunda kelapa. (g) Hasil pengujian hipotesis ketujuhditemukan bukti empiris bahwa secara simultan Shed Occupacy Ratio dan Berth Occupacy Ratioberpengaruh signifikan terhadap Turn Round Time di Pelabuhan sunda kelapa.

\section{Saran}

Berdasarkan hasil penelitian ada beberapa saran Peneliti yang dapat digunakan untuk penelitian mendatang yaitu penelitian diharapkan menambah jumlah variabel bebas dalam penelitian berikutnya seperti Efective Time dan Unit Gang Hour dan variabel operasional pelabuhan lainnya.

\section{Daftar Referensi}

Abbas Salim, H.A. 1993. Manajemen Transportasi, Rajawali Pers, Jakarta.

Calderon, and L Serven, 2004,"The Effects Of Infrastructure Development on Growth and Income Distribution".

Dundovic, Cedomir dan Hess, Svjetlana. 2005. Exploitability of the Port Container Terminal Stacking Area Capacity in the Circumstances of Increased Turnover. ISEP 2005. 
Handoko .2000. Dasar - Dasar Manajemen Produksi dan Operasi, BPFE, Yogyakarta

Idrus et al. 2012. A Study on the Container Yard Utilization of the Major Ports in Indonesia Eastern Region, International Journal of Engineering \& Technology. IJET-IJENS. Vol: 12 No: 03

Jensen \& Meckling. 1976. The Theory of The Firm : Manajerial behavior, Agency Cost and Ownership Structure. Journal of Financial and Economics, 3: 305-360

Kolanovic, I., Skenderovic, J. \&Zenzerovic Z.(2008), "Defining the Port Service Quality Model by using the Factor Analysis", Pomorstvo, 22(2):283-297.

Lasse. 2014. Manajemen Kepelabuhanan. PT Raja Grafindo Persada: Jakarta.

Lasse 2009. Manajemen Muatan : Aktivitas Rantai Pasok di Area Pelabuhan. Penerbit NIKA: Jakarta

Mujeri, M. K, 2002, "Bangladesh, Bringing Poverty Focus in Rural Infrastructure Development". Discussion Paper November 2002 : Issues ini Employment and Poverty Recovery and Reconstrution Departemen International Labour Office, Genewa Musso, E., Ferarri, C. dan Benacchio M., 2006,"Port Investment: Profitability, Economic Impact and Financing", Port Economic, Research in Transportation Economics, Elsevier Vol.16, hlm 171-218.

Nur dan Hadi. 2013.Model Optimisasi Tata Letak Pelabuhan Curah Kering dengan Pendekatan Simulasi Diskrit: Studi Kasus Pelabuhan Khusus PT Petrokimia Gresik,JURNAL TEKNIK POMITS. Vol. 2, No. 1

Putra dan Djalante. 2016. Pengembangan Infrastruktur Pelabuhan Dalam Mendukung Pembangunan Berkelanjutan. Jurnal Ilmiah Media Engineering, Vol.6 No.1

Pattiasina. 2014. Analysis of operational Loading and Unloading Equipment in Sea Transportion, Case Studies in Business and Management Vol. 1, No. 2

Prasetyo dan Vebiastuti. 2000. Manajemen Operasi. Media Presido: Yogyakarta

Setiono 2010. Analisis Faktor-Faktor yang Mempengaruhi Kinerja Pelabuhan.Jurnal Aplikasi Pelayaran dan Kepelabuhanan, Volume 1, Nomor 1

Solossa, Appi Yamsos. 2013. Perencanaan Pengembangan Pekabuhan Laut Sorong di Kota Sorong. Jurnal Jurusan Teknik Sipil. Universitas Sam Ratulangi. Makassar

Supranto. 2000.Statistik: Teori dan Aplikasi, Edisi keenam Cetakan Pertama, Jakarta: Penerbit Erlangga.

Talley., W. K. 2009. Port Economics. First Edition. Routledge. New York.

Tongzon, J. 2002. Port Choice Determinants in a Competitive Environment, IAME Panama 2002 Conference Proceedings.

Triatmodjo, Bambang. 2009. Perencanaan Pelabuhan, Beta Offset: Yogyakarta. 